\title{
Functional Outcomes of Soft Tissue Release Surgery in Advanced Legg- Calve-Perthes Disease
}

\author{
ileri evre Legg - Calve - Perthes hastalarında yumuşak doku gevşetme ameliyatının \\ fonksiyonel sonuçları
}

\author{
Vadym Zhamilovø, Can Doruk Basa®, İsmail Eralp Kaçmaz ๑, Ali Reisoğlu®, Haluk Agus ๑ \\ Tepecik Eğitim ve Araştırma Hastanesi, Ortopedi ve Travmatoloji Kliniği, Izmir
}

Geliş / Received: 07.07.2021 Kabul / Accepted: 18.11.2021 Online Yayın / Published Online: 16.12.2021

Cite as: Zhamilov V., Basa C. D., Kaçmaz I. E., Reisoğlu A., Agus H. Functional Outcomes of Soft Tissue Release Surgery in Advanced Legg-Calve-Perthes Disease Turk J Hip Surg 2021;1(3):84-9

\begin{abstract}
Objectives: This study aimed to investigate the functional and radiological outcomes in Legg-Calvé-Perthes Disease (LCPD) patients undergoing soft tissue release surgery.

Materials and methods: Ten children (11 hips) diagnosed with LCPD who had previously been conservatively treated with movement limitation were included in the study. Patients in the late fragmentation period of the disease were evaluated with arthrography in hip-neutral, abduction, abduction/internal rotation, and adduction positions using radioscopy. Dynamic examination using arthrography was performed to determine whether the patient had any bone pathologies (hinging). For patients with no bone pathology, adductor longus and iliopsoas tenotomy and inferior capsulotomy were performed. Sitting was allowed immediately following surgery, and mobilization with support was allowed after the wound had healed. Patients were followed up at regular intervals. Functional assessments of patients were made using the Harris hip scoring system. Evaluation of radiological imaging was carried out according to the Stulberg classification.

Results: The mean age of patients was 10.9 (6-15) years. According to the Herring lateral pillar classification, one patient was type $B$, three were type $B / C$, and seven were Type C. At the 12-month follow-up, the active range of motion was increased, and hip pain decreased. At the final follow-up (patients followed for 1-5 years; mean: 3 years), one patient was evaluated as type II, seven as type IV, and three as type V according to the Stulberg classification. The mean Harris hip score was 92.3.

Conclusion: Soft tissue release surgery performed as tenotomy in LCPD patients had no effect in terms of radiological characterization, but had positive functional impacts.
\end{abstract}

Keywords: Legg-Calve-Perthes disease; soft tissue release; Harris hip score

öz

Giriş ve Amaç: Bu çalışmanın amacı, yumuşak doku gevşetme ameliyatı uygulanan Legg-Calvé-Perthes (LCPD) hastalarında fonksiyonel ve radyolojik sonuçları araştırmaktır.

Yöntem ve Gereçler: Hareket kısıtıığı nedeniyle konservatif olarak tedavi edilmiş LCPD tanısı almış 10 çocuk (11 kalça) çalışmaya dahil edildi. Geç fragmantasyon dönemindeki hastaların kalçaları artrografi ile kalça nötral, abduksiyon, abduksiyon/iç rotasyon ve adduksiyon pozisyonlarında değerlendirildi. Herhangi bir kemik patolojisi (menteşe) olup olmadığını belirlemek için artrografi ile dinamik muayene yapıldı. Kemik patolojisi olmayan hastalara adduktor longus ve iliopsoas tenotomisiyle birlikte inferior kapsülotomi uygulandı. Ameliyattan hemen sonra oturmaya izin verildi ve yara iyileştikten sonra destekli mobilizasyona izin verildi. Hastalar ameliyattan sonra ortalama 3 (1-5) yıl takip edildi. Hastaların fonksiyonel değerlendirmeleri Harris kalça skorlama sistemi kullanılarak yapıldı. Radyolojik değerlendirilme Herring ve Stulberg sınıflamasına göre yapıldı. Bulgular: Hastaların ortalama yaşı 10.9 (6-15) yıldı. Herring lateral pillar sınıflamasına göre bir hasta tip B, üç hasta tip B/C ve yedi hasta Tip C idi. 12 aylık takipte aktif hareket açıklı̆ının arttğı ve kalça ağrısının azaldığı görüldü. Son kontrolde çekilen röntgenlerde Stulberg sınıflamasına göre bir hasta tip II, yedi hasta tip IV ve üç hasta tip V olarak değerlendirildi. Ortalama Harris kalça skoru 92.3 idi. Tartş̧ma ve Sonuç: LCPD hastalarında yumuşak doku gevşetme ameliyatının radyolojik olarak herhangi bir etkisi olmadığı ancak olumlu fonksiyonel etkileri olduğu sonucuna varıldı.

Anahtar Kelimeler: Legg-Calve- Perthes hastalığı, yumuşak doku gevşetme, Harris kalça skoru

Sorumlu Yazar / Corresponding Author:

Vadym Zhamilov vadymzhamilov@gmail.com
V. Zhamilov 0000-0002-8486-5858 C. D. Basa 0000-0003-1300-7685 i. E. Kaçmaz 0000-0002-2736-140X
A. Reisoğlu $0000-0002-1061-6488$
H. Agus $0000-0003-2831-3642$

(C) Telif hakkı Türkiye Kalça Cerrahisi Dergisi'ne aittir. Diamed Ajans tarafindan yayınlanmaktadır.

Bu dergide yayınlanan makaleler Creative Commons 4.0 Uluslararası Lisansı ile lisanslanmıştır.

(C) Copyright belongs to Turkish Journal of Hip Surgery. It is published by Diamed Agency.

Articles published in this journal are licensed under a Creative Commons 4.0 International License. 


\section{INTRODUCTION}

Legg-Calvé-Perthes Disease (LCPD) is idiopathic avascular necrosis of the femoral head in the pediatric population ${ }^{(1)}$, typically affecting children aged 4-12 years. The exact etiology of the disease is unclear. The affected femoral epiphysis is exposed to varying degrees of self-limiting necrosis, including mild forms without sequelae, resulting in a wide range of severe deformities, including restricted joint movement and early osteoarthritis of the hip ${ }^{(2)}$. Reduced mobility, deformities following necrosis, and early disintegration all have negative impacts on the femoral head, and it is important to maintain hip motion in the late formation period ${ }^{(3)}$. The goals of LCPD treatment includes a wide range of motion (ROM) and hip joint containment ${ }^{(4)}$. Treatment includes casting, bracing, bed rest, mobilization without weight-bearing, physiotherapy, soft tissue release ${ }^{(3,5)}$, femoral osteotomy ${ }^{(6)}$, pelvic osteotomy ${ }^{(7)}$, and combinations of these ${ }^{(8)}$.

Age, gender, and stage at diagnosis are significant for the prognosis ${ }^{(9)}$; however, prognostic estimates may match poorly with patient outcomes ${ }^{(9)}$. Some studies have shown that distraction applied to the hip joint (10) or soft tissue release combined with distraction therapies may restore the joint and increase the physeal height in advanced LCPD(5). However, no studies have reported the results of isolated soft tissue release. The goal of this study was to investigate the functional and radiological outcomes in Legg-CalvéPerthes Disease (LCPD) patients undergoing soft tissue release surgery.

\section{MATERIALS AND METHODS}

We evaluated patients with LCPD who presented at our orthopedics and traumatology clinic between 2012 and 2017 with hip pain and limited ROM. A retrospective evaluation was applied to the patient group in the late fragmentation stage. The results of soft tissue surgery performed in 10 patients (11 hips) with advanced LCPD and limited ROM were evaluated retrospectively. Informed consent was obtained from the patients. Prior ethics committee approval was received from our hospital. Patients with Perthes who had Herring lateral pillar classification types B or C, 6 years or older at presentation, had limitation of hip joint range of motion and pain were included. Exclusion criteria were a history of previous surgery, rheumatologic disorders, patient with hinge abduction, discontinual of follow-up.

\section{Clinical Examination}

The mean age of the patients was 10.9 (6-15) years. This study included six boys and four girls; one girl had bilateral LCPD. The mean follow-up period was $2.9(1-5)$ years. Patients were called for clinical and radiographic follow-up evaluation at 6-month intervals. Pain, ROM, Harris hip score, and ambulation levels were evaluated pre-and postoperatively.

\section{Radiology}

The affected side was characterized according to the Herring and Stulberg classifications. Radiological investigations examined the Shenton line and head-atrisk signs. To characterize the Shenton line, the distance between a line drawn from the lower border of the ramus pubis superior and a line passing through the inferomedial femoral neck was measured. These values were compared before and after surgery.

\section{Surgical Technique}

All patients were in the late fragmentation stage of the disease, as determined via radiology. All surgical procedures were performed by pediatric orthopedic surgeons. Patients were evaluated via arthrography during surgery, accompanied by radioscopy in the neutral, abduction, internal rotation, adduction positions of the hip joint. The presence of bone pathologies (hinging) that could cause joint movement limitation was investigated. Soft tissue release was performed as adductor longus and iliopsoas tenotomy and inferior capsulotomy via a medial approach in patients with no bone pathology (hinging).

Patients were allowed to sit immediately following surgery, and mobilization with support commenced after the wound had healed. Passive joint movement exercises were begun on day 2 postoperatively, and active muscle strengthening exercises in the second week. Patients included in the study were called for follow-up at 6,12 , and 24 weeks postoperatively, and then at 6-month intervals. 


\section{Statistics}

All statistical analyses were performed using SPSS 24.0 (IBM Corporation, Armonk, New York, United States) program. Preoperative and postoperative Harris hip scores and radiological changes were evaluated using the paired-samples t-test. Significance was set at $p<0.05$.

\section{RESULTS}

Of the affected hips, seven were left and four were right. Preoperative radiological (pelvic x-ray) images were evaluated according to Herring lateral pillar classification. One patient was classified as type B, three as type B / C, and seven as Type C. The hips were evaluated functionally according to the Harris hip scoring system. Preoperatively, eight patients exhibited hitching, and two patients were mobilized with support. In the second month of outpatient clinic treatment, average hip flexion ROM increased from $82^{\circ}$ to $95^{\circ}$, and hip pain decreased. At the final follow-up, one patient still showed mild hitching, and all patients were able to walk without support and pain.

AP Shenton line measurements of the pelvis and frog position images showed a reduction in the distance between the line drawn from the lower border of the ramus pubis superior and the inferomedial line of the femur neck in two patients ( $3 \mathrm{~mm}$ and $7 \mathrm{~mm}$ ); however, no change was observed in six patients, and an increase in the distance between the two lines was found in three patients (Table 1). A reduction in the

Table 1. Radiographic changes (head at risk signs ${ }^{(24)}$ )

\begin{tabular}{cccc}
\hline $\begin{array}{c}\text { Patient } \\
\text { No }\end{array}$ & $\begin{array}{c}\text { Head-at-risk } \\
\text { signs }\end{array}$ & $\begin{array}{c}\text { Shenton line breakage }(\mathrm{mm}) \\
\text { preoperative }\end{array}$ & postoperative \\
\hline 1 & 4 & 10 & 7 \\
2 & 4 & 23 & 27 \\
3 & 0 & 0 & 0 \\
4 & 2 & 6 & 6 \\
5 & 2 & 7 & 7 \\
6 & 3 & 1 & 14 \\
7 & 4 & 6 & 6 \\
8 & 4 & 5 & 10 \\
9 & 4 & 19 & 12 \\
10 & 3 & 10 & 9 \\
11 & 3 & 4 & 3 \\
\hline
\end{tabular}

distance on the Shenton fracture line in only two patients revealed that the operation was not effective in terms of this radiological parameter.

The final control $x$-ray images were characterized according to the Stulberg classification. One patient was classified as type II, seven as type IV (Figure 1,2), and three as type $\mathrm{V}$. There was a significant increase in postoperative Harris hip scores $(p<0.001)$, with a mean of 92.3 and range of 81.8-95.9 (Table 2). On average, patients exhibited three head-at-risk signs (range: 0-4).

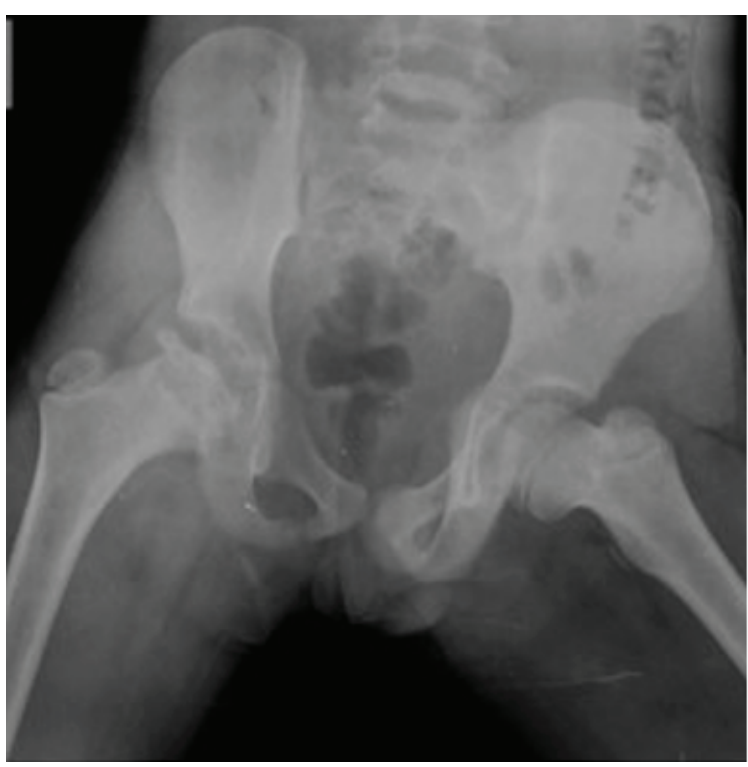

Figure 1. 11y. M. Preoperative radiographs of pelvis AP (') and frog position ("). According to Herring classification: Type C.

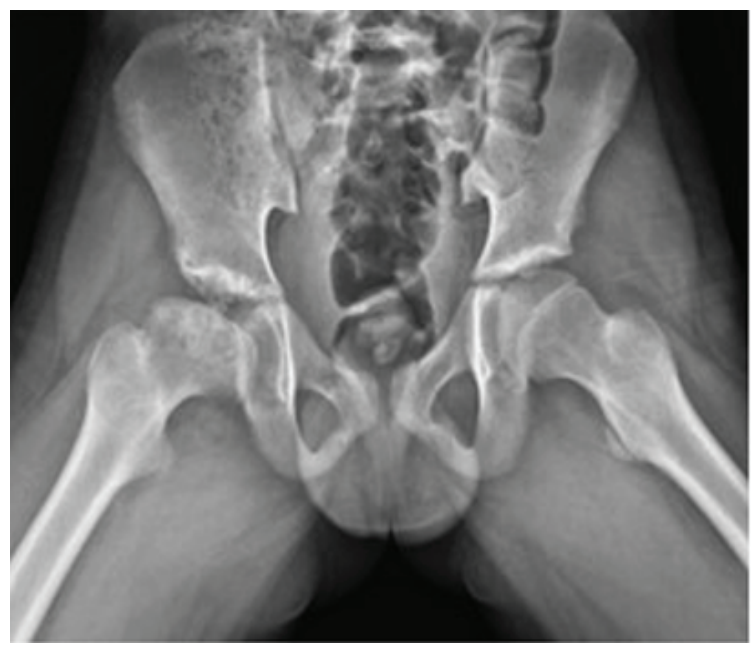

Figure 2. 14y. M. Radiographs of the pelvis AP (') and frog position (“) 3 years after the operation. According to Stulberg classification: Type V. 
Table 2. Radiological and functional characteristics before and after surgery

\begin{tabular}{|c|c|c|c|c|c|c|c|}
\hline No & Gender & $\begin{array}{c}\text { Age } \\
\text { (year) }\end{array}$ & $\begin{array}{l}\text { Mean follow-up } \\
\text { (year) }\end{array}$ & $\begin{array}{c}\text { Preoperative Herring } \\
\text { classification }\end{array}$ & $\begin{array}{c}\text { Harris Hip Score } \\
\text { before surgery }\end{array}$ & $\begin{array}{c}\text { Harris Hip Score } \\
\text { after surgery }\end{array}$ & $\begin{array}{c}\text { Stulberg staging after } \\
\text { surgery }\end{array}$ \\
\hline 1 & $E$ & 11 & 5 & C & 80.7 & 94.8 & 4 \\
\hline 2 & $\mathrm{~K}$ & 15 & 3 & $B / C$ & 67.6 & 81.8 & 5 \\
\hline 3 & $\mathrm{~K}$ & 15 & 3 & B & 78.6 & 85 & 2 \\
\hline 4 & $E$ & 6 & 3 & $B / C$ & 88.8 & 95.2 & 4 \\
\hline 5 & $E$ & 12 & 4 & $\mathrm{C}$ & 44 & 95.8 & 5 \\
\hline 6 & $E$ & 9 & 3 & $B / C$ & 54.4 & 92 & 4 \\
\hline 7 & $E$ & 9 & 3 & $\mathrm{C}$ & 85.8 & 93.8 & 4 \\
\hline 8 & $E$ & 8 & 4 & C & 72.7 & 95.7 & 4 \\
\hline 9 & $\mathrm{~K}$ & 13 & 2 & $C$ & 83.4 & 95.3 & 4 \\
\hline 10 & $\mathrm{~K}$ & 12 & 2 & $C$ & 55.1 & 88.7 & 5 \\
\hline 11 & $\mathrm{~K}$ & 10 & 1 & $\mathrm{C}$ & 41.5 & 95.9 & 4 \\
\hline
\end{tabular}

\section{DISCUSSION}

LCPD starts with avascular necrosis of the femoral head, which may cause changes in the later stages including femoral head deformities, flattening, and hip subluxation ${ }^{(4)}$. The age of onset, ROM, and gender are the most commonly used clinical prognostic indicators, and a long-term meta-analysis showed that age at onset and deformity of the femoral head were the factors that most affected outcomes ${ }^{(11)}$. Pain and limited hip ROM may occur due to deformities and/or muscle contractures when head-acetabulum compliance is impaired. Several treatment strategies have been reported ${ }^{(11)}$; however, poor results have been found in children with advanced LCPD regardless of the intervention ${ }^{(12)}$ and treatment of advanced LCPD remains controversial. The most common goal of treatment is to maintain the femoral head in the acetabulum, which provides head-acetabulum congruity and protects hip movements ${ }^{(4)}$. Thus, surgical interventions should be performed in the early fragmentation ${ }^{(13,14)}$, during which the epiphysis starts to disintegrate, and one or two vertical fissures may be seen ${ }^{(14)}$. During late fragmentation, treatment is aimed at minimizing the effects of deformation of the femoral head ${ }^{(13)}$. Surgical interventions should aim to improve hip congruence by relieving contractures and increasing hip ROM. In the late fragmentation phase, epiphyseal fragmentation is advanced, but no new lateral bone formation is seen in the fragmented epiphysis ${ }^{(14)}$.

An examination of 12 patients who underwent trochanteric epiphysiodesis with soft tissue release ${ }^{(3)}$ showed that surgical intervention prevented iatro- genic deformities of the proximal femur, minimizing trochanteric overgrowth and increasing abductor strength. In a study of 10 patients who underwent external fixator-assisted distraction and soft tissue surgery ${ }^{(5)}$, patient satisfaction was reported as good in terms of both function and pain. In the systemic review, superficial pin tract infection is the most common complication after arthrodiastasis ${ }^{(15)}$. In another study, 2 of 6 patients had infections at the pin tract. They informed that it wasn't a deep infection and was treated with oral antibiotics but sometimes these infections resulted in pulling out of pins earlier than planned ${ }^{(16)}$. Also, some studies have reported the breakage of pins ${ }^{(17)}$. We have as good functional results (mean Harris hip score 92.3) as the study of distraction ${ }^{(5)}$ and didn't have any complications in our patients. Also, ease of application was an important factor.

Recent meta-analysis emphasizes the importance of age at the onset of disease ${ }^{(18)}$. They signify that having enough time for remodeling positively affects the result. In another study, Coates et al. ${ }^{(19)}$ reported good results in patients with the mean age at the onset of 6 years. Paterson et al. ${ }^{(20)}$ reported good results in most of the patients with the mean age at the onset 5 years 10 months. In our study, the mean age of the patients was 10,5 and only 2 patient was 6 and 8 years old. Despite this, satisfactory results were obtained concerning pain and range of motion based on the clinical evaluation.

We can find many reports showing that conservative treatment was less effective in the treatment of Perthes. Kamegaya et al. compared the radiological 
results of patients treated with femoral osteotomy and orthosis treatment at maturity. They reported better outcomes in surgically treated patients according to both Stulberg's and Mose's methods ${ }^{(21)}$. Galloway et al. reported a systematic review that they found only one additional publication assessing

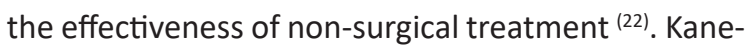
ko et al. informed that Salter osteotomy performed in the initial or fragmentation stage had favorable remodeling capability in hip joint morphology and maintained better congruence during growth in LCPD patients of the onset ages between 6.0 and 8.0 years ${ }^{(23)}$. In this study, we have no control group but most of the studies remarked better results with the surgery group. We made surgery at a late fragmentation stage, and this can explain our postoperative unchanged radiological examination.

We found a reduction in gait abnormalities in all 10 patients and increased Harris hip scores. This suggests that soft tissue release is effective. Our results are consistent with other reports of soft tissue surgery ${ }^{(5)}$. At the final follow-up, all patients were able to walk without support and exhibited improved hip ROM, with Trendelenburg's sign absent in most patients. However, the radiological examination did not indicate that this soft tissue surgical procedure was effective in terms of hip containment. It has been widely reported that treatment of LCPD should aim to ensure hip joint compliance; however, the importance of sustaining ROM has received less attention. We believe that broad hip movement is an important factor for hip joint remodeling.

The limitations of this study include the small number of patients, the relatively short follow-up period, and the absence of a control group. However, we concluded that soft tissue release might be useful in advanced LCPD patients, especially due to its ease of application and the low incidence of complications. This study was carried out in patients with no bone pathology (hinging), as determined by arthrographic examination. On radiological examination, soft tissue release was found to have no effect; however, it resulted in favorable functional scores.

\section{REFERENCES}

1. Rampal V, Clément JL, Solla F. Legg-Calvé-Perthes disease: classifications and prognostic factors. Clin Cases Miner Bone
Metab 2017:14:74-82

https://doi.org/10.11138/ccmbm/2017.14.1.074

2. Stulberg SD, Wallensten R. The natural history of LeggCalve-Perthes disease. J Bone Jt Surg Am 2008;63:1095-08 PMID: 7276045

3. Stevens PM, Anderson LA, Gililland JM, Novais E. Guided growth of the trochanteric apophysis combined with soft tissue release for Legg-Calve-Perthes disease. Strateg Trauma Limb Reconstr 2014;9:37-43. https://doi.org/10.1007/s11751-014-0186-y

4. Li WC, Xu RJ. Lateral shelf acetabuloplasty for severe LeggCalve-Perthes disease in patients older than 8 years: a mean eleven-year follow-up. Med (United States) 2016;95:5272 https://doi.org/10.1097/MD.0000000000005272

5. Segev E, Ezra E, Wientroub S, Yaniv M, Hayek S, Hemo Y. Treatment of severe late-onset Perthes' disease with soft tissue release and articulated hip distraction: revisited at skeletal maturity. J Child Orthop 2007;1:229-35. https://doi.org/10.1007/s11832-007-0046-0

6. Beer $\mathrm{Y}$, Smorgisk $\mathrm{Y}$, Oron $\mathrm{A}$, et al. Long-term results of proximal femoral osteotomy. J Pediatr Orthop 2008;28:819-24. https://doi.org/10.1097/BPO.0b013e31818e122b

7. Thompson GH. Salter osteotomy in Legg-Clve-Perthes disease. J Pediatr Orthop 2011;31:192-97. https://doi.org/10.1097/BPO.0b013e318223b59d

8. Wiig O, Terjesen T, Svenningsen S. Prognostic factors and Outcome of treatment in Perthes' disease: a prospective study of 368 patients with five-year follow-up. J Bone Jt Surg - Ser B 2008;90:1364-71. https://doi.org/10.1302/0301-620X.90B10.20649

9. Catterall A. The natural history of Perthes' disease. J Bone Jt Surg Br 1971;53:37-53. PMID: 5578764

10. Cañadell J, Gonzales F, Barrios RH, Amillo S. Arthrodiastasis for stiff hips in young patients. Int Orthop 1993;17:254-58. https://doi.org/10.1007/BF00194191

11. Kim SS, Lee CW, Kim HJ, Kim HH, Wang L. Treatment of late-onset Legg-Calve-Perthes disease by arthrodiastasis. CiOS Clin Orthop Surg 2016;8:452-57. https://doi.org/10.4055/cios.2016.8.4.452

12. Herring JA, Kim HT BR. Legg-Calve-Perthes disease. Part II: Prospective multicenter study of the effect of treatment on outcome. J Bone Jt Surg Am 2004;86:2121-34. PMID: 15466720

13. Joseph B. Management of Perthes' disease. Indian J Orthop 2015;49:10-16 https://doi.org/10.4103/0019-5413.143906

14. Joseph B, Varghese G, Mulpuri K, Rao K.L.N, Sreekumaran Nair N. Natural evolution of Perthes disease: a study of 610 children under 12 years of age at disease onset. J Pediatr Orthop 2003;23:590-00. https://doi.org/10.1097/00004694-200309000-00005

15. Ibrahim $\mathrm{YH}$, Kersh MA, Fahmy H. Arthrodiastasis in the management of perthes disease: a systematic review. J Pediatr Orthop B 2020;29:550-555.

https://doi.org/10.1097/BPB.0000000000000690

16. Samarah O, Nimer A, Karmi F, Mustafa O, Naser S, Omari L, Hammad Y, Ermeley Z. Role of arthrodiastasis using hinged monolateral external fixator without soft tissue release in advanced stage of Legg-Calve-Perthes disease. Ther Clin Risk Manag 2020;16:1117-24. https://doi.org/10.2147/TCRM.S282404 
17. Sudesh P, Bali K, Mootha AK, Dhillon MS, Saini R. Arthrodiastasis and surgical containment in severe late-onset Perthes disease: An analysis of 14 patients. Acta Orthop Belg 2010;76:329-34.

PMID: 20698453

18. Nguyen N, Klein G, Dogbey G, McCourt JB, Mehlman CT. Operative versus nonoperative treatments for LeggCalve'-Perthes disease: a meta-analysis. J Pediatr Orthop 2012;32:697-05. https://doi.org/10.1097/BPO.0b013e318269c55d

19. Coates CJ, Paterson JM, Woods KR, Catterall A, Fixsen JA. Femoral osteotomy in Perthes' disease. Results at maturity. J Bone Joint Surg Br 1990;72:581-5.

https://doi.org/10.1302/0301-620X.72B4.2380208

20. Paterson DC, Leitch JM, Foster BK. Results of innominate osteotomy in the treatment of Legg-Calve-Perthes disease. Clin Orthop 1991;266:96-103.

PMID: 2019074
21. Kamegaya M, Saisu T, Ochiai N, Hisamitsu J, Moriya H. A paired study of Perthes' disease comparing conservative and surgical treatment. J Bone Joint Surg Br. 2004;86:1176-81. https://doi.org/10.1302/0301-620x.86b8.14458

22. Galloway AM, van-Hille T, Perry DC, Holton C, Mason L, Richards S, Siddle HJ, Comer C. A systematic review of the non-surgical treatment of Perthes' disease. Bone Jt Open 2020;2:720-30. https://doi.org/10.1302/2633-1462.112

23. Kaneko H, Kitoh H, Mishima K, Matsushita M, Hattori T, Noritake $\mathrm{K}$, IshiguroN, Yoshihashi Y. Comparison of surgical and nonsurgical containment methods for patients with LeggCalvé-Perthes disease of the onset ages between 6.0 and 8.0 years: Salter osteotomy versus a non-weight-bearing hip flexion-abduction brace. J Pediatr Orthop B 2020;29:542-49. https://doi.org/10.1097/BPB.0000000000000710

24. Smith SR, Ions GK, Gregg PJ. The radiological features of the metaphysis in Perthes' disease. J Pediatr. https://doi.org/10.1097/01241398-198210000-00009 